\title{
Potential of Laser Induced Breakdown Spectroscopy for analyzing the quality of unroasted and ground coffee
}

\author{
Tiago Varão Silva ${ }^{\mathrm{a}}$, Silviane Zanni Hubinger ${ }^{\mathrm{b}}$, José Anchieta Gomes Neto ${ }^{\mathrm{a}}$, \\ Débora Marcondes Bastos Pereira Milori ${ }^{\mathrm{b}}$, Ednaldo José Ferreira ${ }^{\mathrm{b}}$, Edilene Cristina Ferreira ${ }^{\mathrm{a}, *}$ \\ a São Paulo State University - UNESP, Analytical Chemistry Department, P.O. Box 355, 14801-970 Araraquara, SP, Brazil \\ b Embrapa Instrumentation, P.O. Box 741, 13560-970 São Carlos, SP, Brazil
}

\section{A R T I C L E I N F O}

\section{Article history:}

Received 13 September 2016

Received in revised form 23 June 2017

Accepted 25 June 2017

Available online 28 June 2017

\section{Keywords:}

Coffee global quality

BGS

Classes discrimination

NIRS

LIBS

\begin{abstract}
A B S T R A C T
Coffee is an important commodity and a very popular beverage around the world. Its economic value as well as beverage quality are strongly dependent of the quality of beans. The presence of defective beans in coffee blends has caused a negative impact on the beverage Global Quality (GQ) assessed by cupping tests. The main defective beans observed in the productive chain has been those Blacks, Greens and Sours (BGS). Chemical composition of BGS has a damaging impact on beverage GQ. That is why analytical tools are needed for monitoring and controlling the GQ in coffee agro-industry. Near Infrared Spectroscopy (NIRS) has been successfully applied for assessment of coffee quality. Another potential technique for direct, clean and fast measurement of coffee GQ is Laser Induced Breakdown Spectroscopy (LIBS). Elements and diatomic molecules commonly present in organic compounds (structure) can be assessed by using LIBS. In this article is reported an evaluation of LIBS for the main interferents of GQ (BGS defects). Results confirm the great potential of LIBS for discriminating good beans from those with BGS defects by using emission lines of $C, C N, C_{2}$ and $N$. Most importantly, some emission lines presented strong linear correlation ( $r>0.9$ ) with NIRS absorption bands assigned to proteins, lipids, sugar and carboxylic acids, suggesting LIBS potential to estimate these compounds in unroasted and ground coffee samples.
\end{abstract}

(C) 2017 Elsevier B.V. All rights reserved.

\section{Introduction}

For many years coffee has been one of the most consumed beverages in the world. The International Coffee Organization estimated a world consumption of coffee around 144.8 million of $60 \mathrm{~kg}$ bags in 2015 and the coffee exports in May 2016 in 9.32 million bags [1]. Due to this widespread consumption, the quality is no longer a simple differential to become an essential prerequisite $[2,3]$.

The quality of coffee is related to its organoleptic properties which are result of several factors oscillating from planting to processing postharvest [4]. One of the most important factors for expert tasters (and consumers) is related to bean variety. In general, a high quality coffee is essentially composed by flawless beans from Arabica specie [5], i.e., avoiding excessively blends. Blends of different species and defective beans are the cause of coffee quality depreciation [6].

Among several types of bean defects notable in the Brazilian processing agro-industry, three of them are the most frequent and can be categorized as: Black, Green and Sour (BGS). Black beans are commonly originated from over-ripened beans. Greens are immature fruits known by increasing beverage astringency. Sour beans have the cause of water

\footnotetext{
* Corresponding author.

E-mail address: edilene@iq.unesp.br (E.C. Ferreira).
}

scarcity during development of the fruits or by abnormal fermentation [7]. The presence of BGS defects has a direct impact on demeaning the final beverage quality. The more BGS defects, the less the final beverage quality.

In order to aggregate value and expand internal consumption, the Secretary of Agriculture of São Paulo/Brazil, through the normative resolution (called as: SAA-28) of June 1, 2007 [8] established a technical standard for Brazilian coffee quality certification, based on a score, called Global Quality (GQ), assessed by a panel of experts (experienced tasters), using a very similar methodology to that one recommended by Technical Standards Committee of the Specialty Coffee Association of America (SCAA) for standards for cupping coffee [9]. From GQ coffees are classified as: Traditional (GQ score: 4.5 to 6.0) Superior (GQ score: 6.1 to 7.2 ) and Gourmet (score 7.3 to 10) [10]. Additionally, SAA-28 establishes the maximum contents of BGS defects for Gourmet (0\%), Superior (up to 10\%) and Traditional (up to 20\%) classes [8]. The method for assessing GQ by a panel of experts is expensive, time consuming, demands drink preparation and is rather subjective [11]. Therefore, a simple, fast, low-cost and reliable analytical method is still an essential (important and desirable) tool for an efficient, highly standardized, competitive and modern coffee industry.

Aiming to verify coffee quality authenticity and prevent fraud, several analytical methods have been developed for monitoring and 
(a)

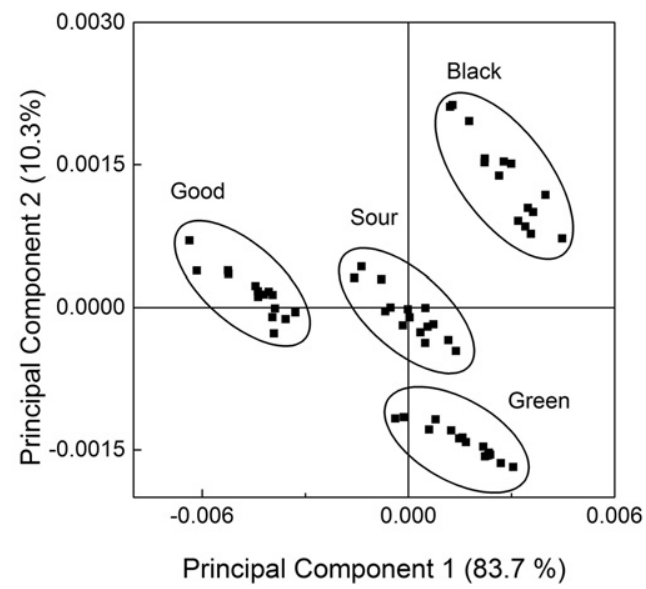

(b)

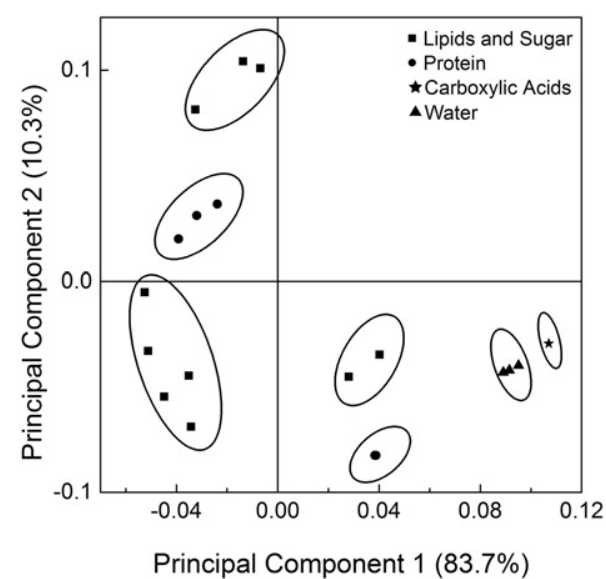

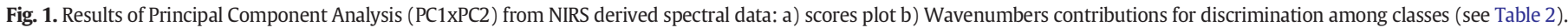

classifying the coffee beans [12,13]. Among the analytical techniques commonly applied to that purpose, Near Infrared Spectroscopy (NIRS) has been outstanding with good results [14-16]. The NIRS shows advantages over others dedicated to organic composition analysis (e.g. chromatography), since it performs direct, fast and low-cost analysis, dispensing complex procedures for samples (minimal pretreatment). Absorption bands in NIRS spectrum provide information about organic molecular compounds present in sample [17]. Thus, NIRS has an enormous potential for discriminating
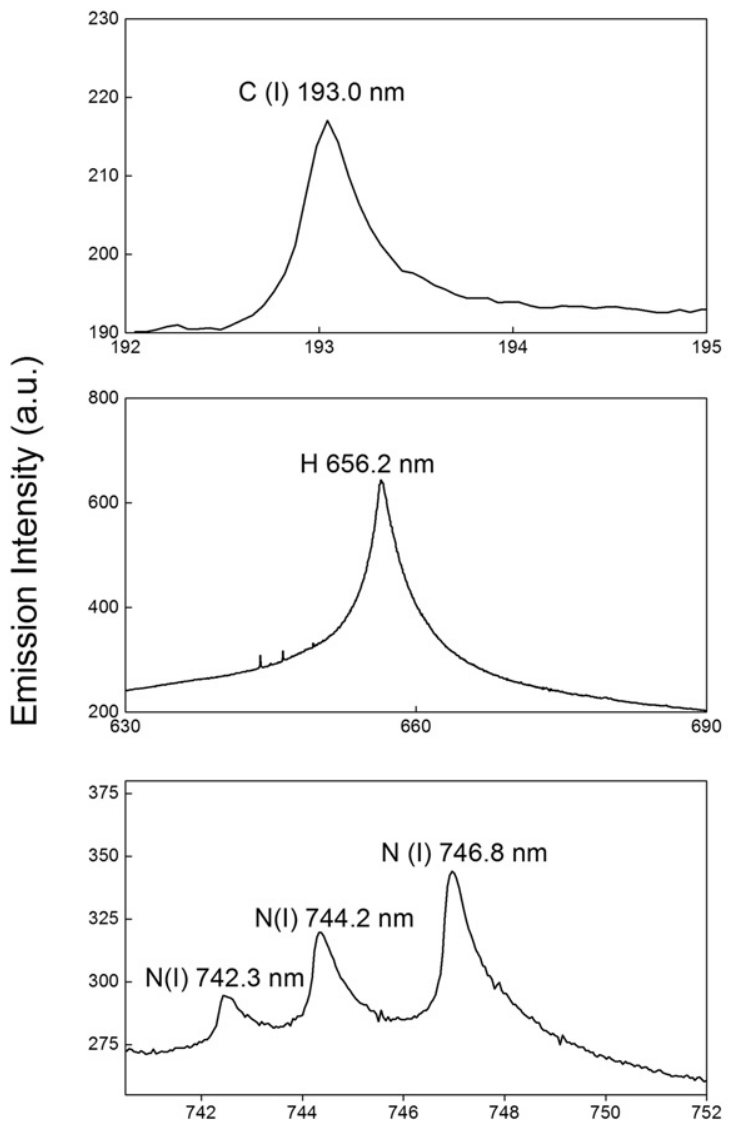

different coffee classes, since there exist organic composition differences among them [5].

On the other hand, a more complete chemical profile for different coffee beans (including BGS defects) can extend current knowledge to beyond the molecular comprehension, providing scientific novelty and making technological development viable for analyzing quality tasted in coffee cupping.

Different methods based on atomic absorption and emission spectroscopy have been used to determine concentrations of elements in
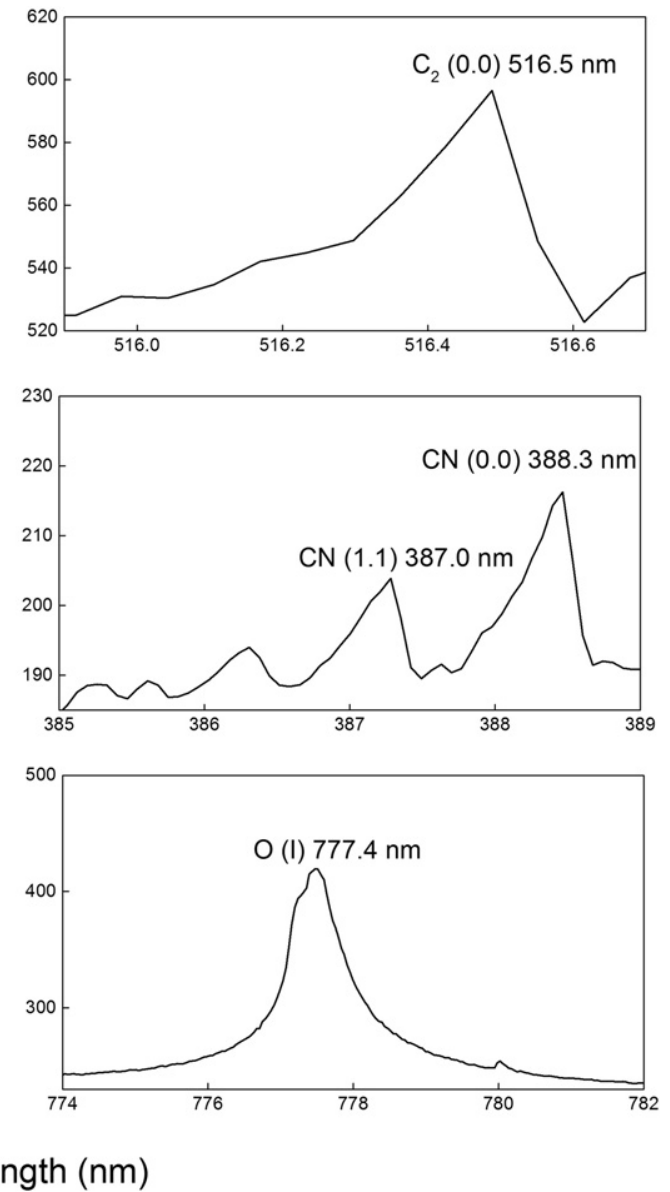

Fig. 2. Fragments of medium LIBS spectrum $(n=40)$ of good coffee sample in different spectral regions of the selected lines. 
coffee samples [18]. In general, these techniques need an adequate sample preparation, some of them involving complicated procedures of acid decomposition in high temperatures. In this context, the technique Laser Induced Breakdown Spectroscopy (LIBS) stands out as an interesting alternative. LIBS is based on application of short energetic laser pulses, directly in sample surface. Laser pulse removes a reduced mass of sample, vaporizes it and produces a plasma. Breakdown of sample compounds and species excitation occurs as a result of laser pulse and the plasma action. The evaluation of the recorded light emission intensity, arising from the de-excitation processes, permits a qualitative and sometimes quantitative sample characterization [19]. As LIBS is directly performed on solid samples, a sample pretreatment is practically unnecessary. Although direct analysis may result in precision reduction, speed and lower cost per analysis make viable a high number of analyzes per sample, which improves representativeness [20,21].

LIBS potential has also been exploited for classification of organic compounds in biological materials [20], oils [22] and explosives [23]. These applications are possible because of emission lines of major elements present in organic compounds, such as C, H, N and O $[22,23]$ as well as lines corresponding to emission bands of diatomic molecules, such as $\mathrm{CN}$ [24] and $\mathrm{C}_{2}$ [23]. Additionally, LIBS has also been investigated for determination of other samples properties such as $\mathrm{pH}$ and soil texture with high correlation among properties and emission lines $[25,26]$.

Ferreira et al. (2011) [27] applied LIBS for classification of roasted coffees according to their respective GQ classes (Gourmet, Superior, Traditional and Inferior). According to them, wavelengths in the region of the hydrogen emission line (close to $680 \mathrm{~nm}$ ) were useful to build a high accurate ensemble of decision trees for classification of roasted and ground coffees (commercially available).

An increasing demand for coffee quality certification in the world market brings with it an emergent necessity of techniques endowed with features like those immanent in LIBS. Thus, the aim of this study was investigating elemental and molecular compositions by using LIBS (establishing LIBS-NIRS correlations) to thereby demonstrate its potential for distinguishing classes of coffee beans, especially among good beans and BGS defects, as previous discrimination task intrinsically (and strongly) linked to the GQ of the resultant coffee drink. Elemental and molecular emission lines were analyzed by observing the highest correlations to molecular bands of $\mathrm{C}-\mathrm{H}, \mathrm{C}=\mathrm{O}$ and $\mathrm{O}-\mathrm{H}$ assessed through NIRS spectrum.

\section{Material and methods}

Samples of coffee beans (Arabic specie from the same crop) classified by an expert as "good" (good quality/no defects), "black", "green" and "sour" were provided by a Brazilian coffee cooperative of Minas Gerais state. All samples were submitted to a cryogenic grinding, using grinding cycle of $2.0 \mathrm{~min}$, followed by $3.0 \mathrm{~min}$ of sample refreezing and other grinding cycle of $2.0 \mathrm{~min}$.

\subsection{Sample analysis}

The NIRS instrument used for analysis was a near infrared spectrometer, model Spectrum 100 N (Perkin-Elmer Corp., Norwalk, CT) covering $4000-10,000 \mathrm{~cm}^{-1}$ range of wavenumbers with spectral resolution of $2 \mathrm{~cm}^{-1}$. Masses around $2.0 \mathrm{~g}$ were placed in a glass cuvette, which was introduced over the sample holder of the spectrometer. For each of one of the five sample repetition per class, three measurements were carried. Each measurement corresponded to 32 averaged spectra.

For LIBS analysis, five pellets of each coffee class were prepared by applying 10 tons in $200 \mathrm{mg}$ of ground samples. The pellets were placed in sample holder of a LIBS system. The mentioned equipment comprises seven spectrometers (model LIBS2500 from Ocean Optics, USA) with resolution around $0.1 \mathrm{~nm}$ (FWHM) for the spectral analysis ranging from 188 to $980 \mathrm{~nm}$, a Q-switched Nd:YAG laser at $1064 \mathrm{~nm}$, manufactured by Quantel (Big Sky Laser Ultra50), an ablation chamber, a lens for laser focalization $(10 \mathrm{~cm}$ of focal distance) and an optical system to collect plasma emission and to conduct it the spectrometers made up of a lens and a fiber optic bundle. All measurements were acquired by setting a pulse energy of $50 \mathrm{~mJ}$ with $8 \mathrm{~ns}$ duration, resulting in an output laser fluency around $0.3 \mathrm{~J} \mathrm{~cm}^{-2}$ and an irradiance in focal point around $10^{12} \mathrm{~W} \mathrm{~cm}^{-2}$. The delay time (relative to a Q-switch delay) used was $11 \mu$ s and the fixed system instrumental conditions of integration time $2.1 \mathrm{~ms}$. Laser pulses were spread on both sides of each pellet. Forty spectra were obtained from each prepared pellet resulting in 200 spectra per class of samples, since five pellets of each class were analyzed.

\subsection{Data processing}

NIRS spectra show undesirable effects like light scattering, which can account negatively to the results interpretation. Then an adequate spectral treatment is important to minimize these effects [17]. First derivative was chosen for this proposal considering its simplicity $[17,28]$. Therefore each mean spectrum (average of 32 spectra) acquired by the instrument was differentiated. A Principal Component Analysis (PCA) was carried on considering derivative spectra. Pirouette ${ }^{\circledR} 4.5$ (Infometrix) software was used for PCA and the data were mean centering. The spectral bands responsible for separating the coffee classes

Table 1

Coffee classes discrimination according to LIBS emission lines.

\begin{tabular}{|c|c|c|}
\hline $\begin{array}{l}\text { Emission } \\
\text { line }\end{array}$ & $\begin{array}{l}\text { Significant difference between } \\
\text { classes }(p \text {-value }<0.05)\end{array}$ & $\begin{array}{l}\text { No significant difference between } \\
\text { classes }(p \text {-value }>0.05)\end{array}$ \\
\hline $\begin{array}{l}\text { C (I) } 193.0 \\
\text { nm }\end{array}$ & $\begin{array}{l}\text { Green - Good } \\
\text { Black - Good } \\
\text { Sour - Good }\end{array}$ & $\begin{array}{l}\text { Green - Black } \\
\text { Green - Sour } \\
\text { Black - Sour }\end{array}$ \\
\hline $\mathrm{CN}(1.1)$ & Green - Good & Green - Black \\
\hline 387.0 & Black - Good & Green - Sour \\
\hline $\mathrm{nm}$ & Sour - Good & Black - Sour \\
\hline $\begin{array}{c}\mathrm{CN}(0.0) \\
\quad 388.5 \\
\mathrm{~nm}\end{array}$ & $\begin{array}{l}\text { Green - Good } \\
\text { Black - Good } \\
\text { Sour - Good } \\
\text { Green - Sour } \\
\text { Black - Sour } \\
\text { Green - Black }\end{array}$ & \\
\hline $\begin{array}{c}C_{2}(0.0) \\
\quad 516.6 \\
n m\end{array}$ & $\begin{array}{l}\text { Green - Good } \\
\text { Black - Good } \\
\text { Sour - Good } \\
\text { Green - Sour } \\
\text { Black - Sour }\end{array}$ & Green - Black \\
\hline $\begin{array}{l}\mathrm{H} 656.2 \\
\mathrm{~nm}\end{array}$ & $\begin{array}{l}\text { Green - Good } \\
\text { Black - Green }\end{array}$ & $\begin{array}{l}\text { Green - Sour } \\
\text { Black - Good } \\
\text { Black - Sour } \\
\text { Sour - Good }\end{array}$ \\
\hline $\begin{array}{l}\mathrm{N}(\mathrm{I}) 742.3 \\
\mathrm{~nm}\end{array}$ & $\begin{array}{l}\text { Green - Black } \\
\text { Green - Good } \\
\text { Black - Good } \\
\text { Good - Sour }\end{array}$ & $\begin{array}{l}\text { Green - Sour } \\
\text { Black - Sour }\end{array}$ \\
\hline $\begin{array}{l}\mathrm{N}(\mathrm{I}) 744.2 \\
\mathrm{~nm}\end{array}$ & $\begin{array}{l}\text { Green - Black } \\
\text { Green - Good } \\
\text { Black - Good } \\
\text { Good - Sour } \\
\text { Green - Sour }\end{array}$ & Black - Sour \\
\hline $\begin{array}{l}\mathrm{N}(\mathrm{I}) 746.8 \\
\mathrm{~nm}\end{array}$ & $\begin{array}{l}\text { Green - Black } \\
\text { Green - Good } \\
\text { Black - Good } \\
\text { Good - Sour } \\
\text { Green - Sour }\end{array}$ & Black - Sour \\
\hline $\begin{array}{l}\mathrm{O}(\mathrm{I}) 777.4 \\
\mathrm{~nm}\end{array}$ & $\begin{array}{l}\text { Green - Black } \\
\text { Green - Good } \\
\text { Green - Sour } \\
\text { Black - Sour }\end{array}$ & $\begin{array}{l}\text { Black - Good } \\
\text { Sour - Good }\end{array}$ \\
\hline
\end{tabular}


(a)

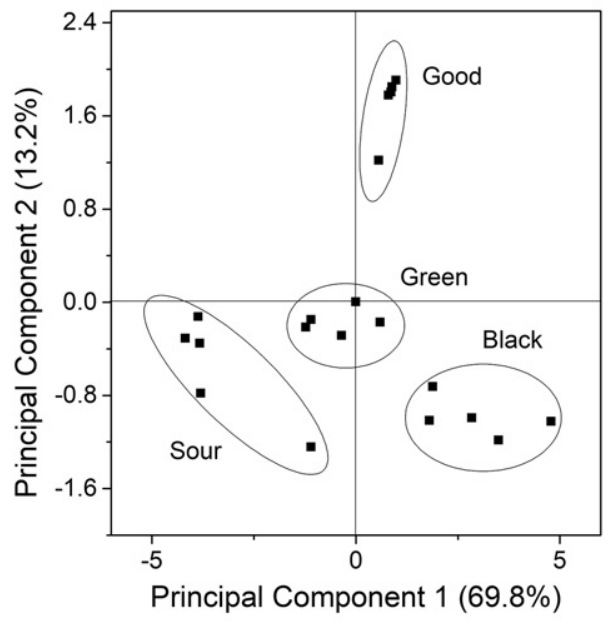

(b)

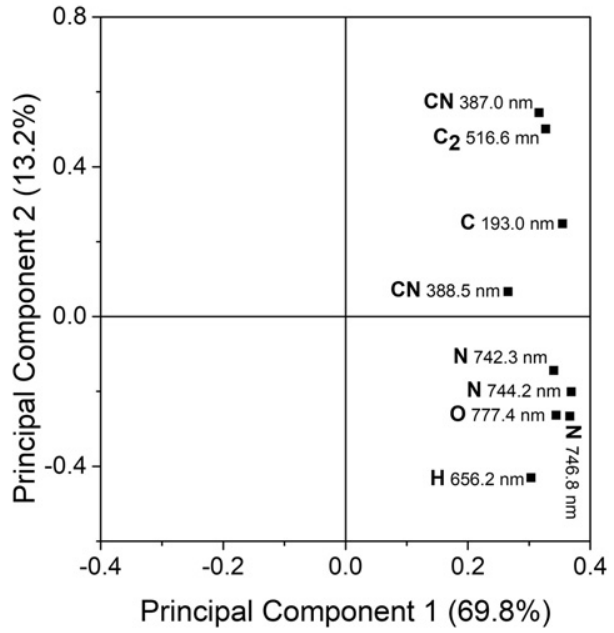

Fig. 3. Results of Principal Component Analysis (PC1xPC2) from LIBS derived spectral data: a) scores plot b) Species contributions for discrimination among classes (see Table 1).

were identified and associated with the compounds present in the samples.

In LIBS spectra, emission lines corresponding to species commonly present in organic molecules were selected: C (I) $193.0 \mathrm{~nm}, \mathrm{CN}$ (0.0) $387.0 \mathrm{~nm}, \mathrm{CN}$ (1.1) $388.5 \mathrm{~nm}, \mathrm{C}_{2}$ (0.0) $516.6 \mathrm{~nm}, \mathrm{H} 656.2 \mathrm{~nm}$, $\mathrm{N}$ (I) $742.3 \mathrm{~nm}, \mathrm{~N}$ (I) $744.2 \mathrm{~nm}, \mathrm{~N}$ (I) $746.8 \mathrm{~nm}$ and O (I) $777.4 \mathrm{~nm}$. For all selected lines, Voigt functions were fitted and then integrated (area under the curve). An average spectrum corresponding to each coffee class was obtained (average of 200 spectra). Significant differences among means from coffee classes were assessed by using Analysis of Variance (ANOVA) with Tukey test (significance level equal to 0.05 ) for pairwise comparisons. Additionally a PCA was applied to the autoscaled data.

Afterwards, LIBS spectra were processed by first derivative only to get the same mathematical transformation applied to NIRS spectra, making possible a direct correlation (rate of change in LIBS vs. rate of change in NIRS). Derivative spectra from each coffee class for both analytical techniques were averaged, and then linear correlations between narrow ranges (peak interval) of emission lines (LIBS) and NIRS bands $(\mathrm{C}-\mathrm{H}, \mathrm{C}=\mathrm{O}$ and $\mathrm{O}-\mathrm{H}$ ) were assessed exactly on inflection points (minimum value of the first derivative) of the interest regions.

\section{Results and discussion}

Discrimination of coffee classes from the NIRS results were clearly observed by PCA plot. The results of this analysis are shown in Fig. 1, where PC1 represents $83.7 \%$ and PC2 10.3\% of total data variance. Ellipses were draw to guide the eyes for the clustering of the classes. In Fig. 1b can be observed contributions for PCs. There are strong indications that main absorption bands are contributing for a clear discrimination among classes, i.e., $\mathrm{C}-\mathrm{H}$ at $4244-4350 \mathrm{~cm}^{-1}$ from lipids, sugars and proteins, $\mathrm{C}=0$ at about $5260 \mathrm{~cm}^{-1}$ from carboxylic acid and $\mathrm{O}-\mathrm{H}$ at $5280-5286 \mathrm{~cm}^{-1}$ from water [2]. The Fig. $1 \mathrm{~b}$ indicates that good beans, distinct by PC1, contain higher amounts of lipids, sugars and/or proteins. The green class, discriminated from the black and sour shows also proteins, lipids and sugars besides of the highest amounts of water and carboxylic acids. The sour class shows intermediate amounts of the mentioned compounds while black class shows lower amounts of these compounds. The color of black beans is result of a non enzimatic browning known as Maillard reactions, i.e. reactions between carbonyl groups of the sugars with the nucleophilic amino group of the amino acids [29]. As carboxylic acids and proteins are consumed in Maillard reaction these compounds were lower in black class.

Table 2

Linear correlation coefficient (in module) for differentiated minimum inflections of LIBS and NIRS signals.

\begin{tabular}{|c|c|c|c|c|c|c|c|c|c|c|}
\hline \multirow{3}{*}{$\begin{array}{l}\text { Wavenumber } \\
\text { attribution }\end{array}$} & \multirow{3}{*}{$\begin{array}{l}\text { NIRS wave number } \\
(\mathrm{cm}-1)\end{array}$} & \multicolumn{9}{|c|}{ LIBS wavelength (nm) } \\
\hline & & C (I) 193.0 & $\mathrm{CN}(1.1)$ & $\mathrm{CN}(0.0)$ & $\mathrm{C} 2(0.0)$ & $\mathrm{H}$ & N (I) 742.3 & $\mathrm{~N}(\mathrm{I}) 744.2$ & $\mathrm{~N}(\mathrm{I}) 746.8$ & $\mathrm{O}(\mathrm{I})$ \\
\hline & & & 387.2 & 388.5 & 516.6 & 656.2 & & & & 777.4 \\
\hline \multirow[t]{3}{*}{ Protein } & 4244 & 0.894 & 0.821 & 0.815 & 0.663 & 0.948 & 0.935 & 0.922 & 0.898 & 0.872 \\
\hline & 4246 & 0.958 & 0.908 & 0.902 & 0.766 & 0.881 & 0.885 & 0.852 & 0.830 & 0.779 \\
\hline & 4248 & 0.990 & 0.962 & 0.956 & 0.839 & 0.799 & 0.818 & 0.768 & 0.748 & 0.675 \\
\hline \multirow[t]{9}{*}{ Lipids, sugars and oils } & 4256 & 0.903 & 0.955 & 0.951 & 0.924 & 0.348 & 0.415 & 0.315 & 0.309 & 0.175 \\
\hline & 4266 & 0.970 & 0.802 & 0.796 & 0.640 & 0.958 & 0.942 & 0.933 & 0.908 & 0.887 \\
\hline & 4270 & 0.965 & 0.919 & 0.913 & 0.782 & 0.868 & 0.874 & 0.838 & 0.816 & 0.761 \\
\hline & 4314 & 0.289 & 0.157 & 0.162 & 0.020 & 0.859 & 0.763 & 0.845 & 0.810 & 0.916 \\
\hline & 4318 & 0.745 & 0.650 & 0.652 & 0.507 & 0.980 & 0.927 & 0.950 & 0.914 & 0.942 \\
\hline & 4324 & 0.993 & 0.997 & 0.996 & 0.923 & 0.651 & 0.579 & 0.613 & 0.592 & 0.501 \\
\hline & 4326 & 0.964 & 0.993 & 0.992 & 0.944 & 0.510 & 0.482 & 0.472 & 0.457 & 0.345 \\
\hline & 4328 & 0.910 & 0.961 & 0.960 & 0.939 & 0.362 & 0.379 & 0.326 & 0.315 & 0.188 \\
\hline & 4330 & 0.816 & 0.892 & 0.892 & 0.904 & 0.182 & 0.251 & 0.147 & 0.141 & 0.003 \\
\hline \multirow{2}{*}{ Protein } & 4348 & 0.803 & 0.711 & 0.704 & 0.538 & 0.986 & 0.915 & 0.965 & 0.939 & 0.940 \\
\hline & 4350 & 0.800 & 0.707 & 0.701 & 0.536 & 0.986 & 0.907 & 0.965 & 0.938 & 0.940 \\
\hline Carboxil acids & 5264 & 0.990 & 0.961 & 0.941 & 0.793 & 0.768 & 0.640 & 0.754 & 0.752 & 0.647 \\
\hline \multirow{3}{*}{ Water } & 5280 & 0.983 & 0.945 & 0.923 & 0.764 & 0.801 & 0.653 & 0.790 & 0.788 & 0.689 \\
\hline & 5284 & 0.980 & 0.940 & 0.919 & 0.758 & 0.811 & 0.657 & 0.800 & 0.798 & 0.701 \\
\hline & 5286 & 0.979 & 0.937 & 0.916 & 0.754 & 0.817 & 0.661 & 0.806 & 0.803 & 0.708 \\
\hline
\end{tabular}


The above results suggest that proteins, lipids, sugar and carboxylic acids besides the water are important chemical compounds for discrimination of coffee classes and these compounds can be measured by NIRS to infer the coffee quality.

Whereas proteins, lipids, sugar, water and carboxylic acids are relevant for discrimination among coffee classes, emission lines of elements or diatomic species mostly present in the structures of these compounds were selected from LIBS spectra for evaluation. The selected lines in LIBS spectra can be observed in Fig. 2.

The coffee classes were compared considering medium areas of each selected emission lines. The significant differences ( $p$-value $<$ 0.05 ) among the classes in function of selected emission lines are shown in Table 1. For clarifying result visualizations a PCA was performed. Scores and loading plots are shown in Fig. 3. Except for the $\mathrm{H} 656.2 \mathrm{~nm}$ and $\mathrm{O}$ (I) $777.4 \mathrm{~nm}$ lines, the other lines are suitable to be used for discrimination of good beans. These results emphasize LIBS potential for detecting improper blends of BGS defects in Gourmet coffees (100\% good beans). Furthermore, it is highlighted the potential of the lines of $\mathrm{CN}(0.0) 388.5 \mathrm{~nm}, \mathrm{C}_{2}(0.0) 516.6 \mathrm{~nm}, \mathrm{~N}(\mathrm{I})$ $744.2 \mathrm{~nm}$ and $\mathrm{N}(\mathrm{I}) 746.8 \mathrm{~nm}$ for discrimination of the mostly studied classes.

A study was carried out to check the correlations between NIRS absorption bands and LIBS emission lines. All pairwise correlation (using linear correlation as a metric) were applied to values extracted from inflection points. The results of linear correlation (in module) are shown in Table 2.

Absorption bands corresponding to proteins, lipids, sugar and carboxylic acids and emission lines of C(I) $193.0 \mathrm{~nm}, \mathrm{CN}$ (1.1) $387.0 \mathrm{~nm}$, $\mathrm{CN}(0.0) 388.5 \mathrm{~nm}$ showed correlation coefficient higher than $0.9 \mathrm{sug}-$ gesting the potential of these emission lines to estimate classes of compounds in coffee samples by using only LIBS technique. The triplet of nitrogen, N (I) $742.3 \mathrm{~nm}, 744.2 \mathrm{~nm}$ and $746.8 \mathrm{~nm}$, have potential for a linear modeling capable of estimating protein contents as well as $C_{2}$ (0.0) $516.6 \mathrm{~nm}$ for lipids, since these lines showed high correlation with respective NIRS absorption bands $(r \geq 0.9)$. It is highlighted that $\mathrm{CN}$ emission band at $388.5 \mathrm{~nm}$ provided the best class discriminations and it was strongly correlated to coffee proteins (Table 2), suggesting that $\mathrm{CN}$ monitored lines are predominantly from protein molecular fragmentations.

The LIBS and NIRS techniques show similar features in terms of analytical simplicity, direct and fast analysis and portability potential. On the other hand, results suggest that LIBS can be capable of performing some kind of analysis similarly to NIRS, besides its ability to analyze the elemental composition, which is not feasible by using NIRS.

\section{Conclusion}

The quality of coffee is strongly linked to blends with defective beans. Black, Green and Sour beans damage beverage quality. Thus, the development of tools for detection of coffee quality adulteration is very important for world coffee agro-industry. LIBS technique showed a high potential for discriminating good beans from BGS defects from unroasted ground coffee. Emission lines of elements and emission bands of diatomic molecules derived from organic compounds showed good discriminant power. The high correlations $(r>0.9)$ observed for $\mathrm{N}, \mathrm{CN}, \mathrm{C}$ and $\mathrm{C}_{2}$ LIBS emissions and NIRS absorption bands of proteins, lipids, sugars and carboxylic acids also suggest the potential of LIBS for estimation of these compounds. Finally, more than a multielemental determination, LIBS has shown a capacity for aggregating information on molecular and organic aspects (a particular feature attributed to NIRS) related to quality of coffee beans, and consequently coffee beverage resultant from them. These findings confirm LIBS as a promising tool for analyzing food quality in many agro-industry branches.

\section{Acknowledgement}

Special thanks to Coffee Research Consortium (Brazilian Ministry of Agriculture and Embrapa, Grant \# 04.13.02.003.00.0) for supporting research through MP4 project.

\section{References}

[1] ICO, International Coffee Organization. http://www.ico.org/, 2016 (accessed 26 July 2016)

[2] N. Yang, C. Liu, X. Liu, T.K. Degn, M. Munchow, I. Fisk, Determination of volatile marker compounds of common coffee roast defects, Food Chem. 211 (2016) 206-214.

[3] W.B. Sunarharum, D.J. Williams, H.E. Smyth, Complexity of coffee flavor: a compositional and sensory perspective, Food Res. Int. 62 (2014) 315-325.

[4] A.T. Toci, A. Farah, Volatile fingerprint of Brazilian defective coffee seeds: corroboration of potential marker compounds and identification of new low quality indicators, Food Chem. 153 (2014) 298-314.

[5] Yi-Fang Chu, Coffee: Emerging Health Effects and Disease Prevention, First Edition John Wiley \& Sons, Blackwell Publishing Inc, Iowa, 2012.

[6] A. Farah, M.C. Monteiro, V. Calado, A.S. Franca, L.C. Trugo, Correlation between cup quality and chemical attributes of Brazilian coffee, Food Chem. 98 (2006) 373-380.

[7] A.T. Toci, A. Farah, Volatile compounds as potential defective coffee beans' markers, Food Chem. 108 (2008) 1133-1141.

[8] Codeagro, Resolução SAA - 28, de 01 de junho de, 2007 http://www.codeagro. agricultura.sp.gov.br/arquivos/selo/saa_28a191a62ed1008f350553a619ba36f7e7. pdf, 2016 (accessed 07.27.2016).

[9] F.M. Borém, F.C. Ribeiro, L.P. Figueiredo, G.S. Giomo, V.A. Fortunato, E.P. Isquierdo, Evaluation of the sensory and color quality of coffee beans stored in hermetic packaging, J. Stored Prod. Res. 52 (2013) 1-6.

[10] Specialty Coffee Association of America (SCAA), Cupping Specialty Coffee, 2016 http:// www.scaa.org/PDF/resources/cupping-protocols.pdf, 2016 (accessed 07.27.2016).

[11] K. Tolessa, M. Rademaker, B. De Baets, P. Boeckx, Prediction of specialty coffee cup quality based on near infrared spectra of green coffee beans, Talanta 150 (2016) 367-374.

[12] M. Oliveira, S. Casal, S. Morais, C. Alves, F. Dias, S. Ramos, E. Mendes, C. DelerueMatos, M. Beatriz, P.P. Oliveira, Intra- and interspecific mineral composition variability of commercial instant coffees and coffee substitutes: contribution to mineral intake, Food Chem. 130 (2012) 702-709.

[13] R.M. Barbosa, B.L. Batista, R.M. Varrique, V.A. Coelho, A.D. Campiglia, F. Barbosa, The use of advanced chemometric techniques and trace element levels for controlling the authenticity of organic coffee, Food Res. Int. (2013).

[14] A.P. Craig, A.S. Franca, L.S. Oliveira, J. Irudayaraj, K. Ileleji, Fourier transform infrared spectroscopy and near infrared spectroscopy for the quantification of defects in roasted coffees, Talanta 134 (2015) 379-386.

[15] J.R. Santos, M.C. Sarraguça, A.O.S.S. Rangel, J.A. Lopes, Evaluation of green coffee beans quality using near infrared spectroscopy: a quantitative approach, Food Chem. 135 (2012) 1828-1835.

[16] E. Bertone, A. Venturello, A. Giraudo, G. Pellegrino, F. Geobaldo, Simultaneous determination by NIR spectroscopy of the roasting degree and Arabica/Robusta ratio in roasted and ground coffee, Food Control 59 (2016) 683-689.

[17] C. Pasquini, Near infrared spectroscopy: fundamentals, practical aspects and analytical applications, J. Braz. Chem. Soc. 14 (2003) 198-219.

[18] P. Pohl, E. Stelmach, M. Welna, A. Szymczycha-Madeja, Determination of the elemental composition of coffee using instrumental methods, Food Anal. Methods 6 (2013) 598-613.

[19] D. Cremers, L.J. Radziemski, Handbook of Laser-Induced Breakdown Spectroscopy, John Wiley \& Sons, Chichester, 2006.

[20] S.J. Rehse, H. Salimnia, A.W. Miziolek, Laser-induced breakdown spectroscopy (LIBS): an overview of recent progress and future potential for biomedical applications, J. Med. Eng. Technol. 36 (2012).

[21] A.W. Miziolek, V. Palleschi, I. Schechter, LIBS Fundamentals and Applications, Cambridge, 2006.

[22] Y.G. MbesseKongbonga, H. Ghalila, M.B. Onana, Z. Ben Lakhdar, Classification of vegetable oils based on their concentration of saturated fatty acids using laser induced breakdown spectroscopy (LIBS), Food Chem. 147 (2014) 327-331.

[23] P. Lucena, A. Doña, LM. Tobaria, JJ. Laserna, New challenges and insights in the detection and spectral identification of organic explosives by laser induced breakdown spectroscopy, Spectrochim. Acta B 66 (2011) 12-20.

[24] Á. Fernández-Bravo, T. Delgado, P. Lucena, J.J. Laserna, Vibrational emission analysis of the CN molecules in laser-induced breakdown spectroscopy of organic compounds, Spectrochim. Acta B At. Spectrosc. 89 (2013) 77-83.

[25] E.C. Ferreira, J.A. Gomes Neto, D.M.B.P. Milori, E.J. Ferreira, J.M.A. Lacarte, Laser-induced breakdown spectroscopy: extending its application to soil $\mathrm{pH}$ measurements, Spectrochim. Acta B At. Spectrosc. 110 (2015) 96-99.

[26] P.R. Villas-Boas, R.A. Romano, M.A. de Menezes Franco, E.C. Ferreira, E.J. Ferreira, S. Crestana, D.M.B.P. Milori, Laser-induced breakdown spectroscopy to determine soil texture: a fast analytical technique, Geoderma 263 (2016) 195-202.

[27] E.J. Ferreira, E.C. Ferreira, A.C.B. Delbem, D.M.B.P. Milori, Ensemble of predictors and laser induced breakdown spectroscopy for certifying coffee, Electron. Lett. 47 (2011) 967-969.

[28] D. Burns, E. Ciurczak, Handbook of Near-Infrared Analysis Second Edition, Revised and Expanded Edited, Marcel Dekker, New York, 2007.

[29] A. Farah, C.M. Donangelo, Phenolic compounds in coffee, Braz. J. Plant Physiol. 18 (2006) 23-36. 